\title{
粗粒材養浜に伴う細砂の堆積助長と碟の打込み予測 \\ Prediction of Deposition of Fine Sand in Beach Nourishment Using Gravel and Shoreward Movement of Gravel During Storm
}

\author{
古谷真広 $^{1}$ ・ 小林昭男 ${ }^{2} \cdot$ 宇多高明 ${ }^{3} \cdot$ 野志保仁 $^{4}$
}

\author{
Masahiro KOYA, Akio KOBAYASHI, Takaaki UDA and Yasuhito NOSHI
}

\begin{abstract}
On the Akashi coast, beach nourishment using gravel with the grain size ranging between 3 and $13 \mathrm{~mm}$ was begun in November 2008. The beach changes were monitored using the photographs from several fixed points. It was found that fine sand was deposited over the gravel layer under the calm wave conditions, whereas the nourished gravel was transported onshore and deposited in front of the seawall under the storm wave conditions. Assuming that the equilibrium slope changes in response to the change in thickness of sand layer, a model for predicting the deposition of fine sand over the gravel layer in beach nourishment using gravel and the shoreward movement of gravel during storms was developed on the basis of the contour-line-change model.
\end{abstract}

\section{1. まえがき}

鹿島灘に面した茨城県神向寺海岸では，2005年11月〜 2008年 4 月に粒径3〜 13mmの礫を用いた粗粒材養浜が行 われ, 前浜が復元された（松浦ら，2009）。この成功を 受けて, 神向寺海岸の北に隣接する明石海岸でも2008年 11 月 11 日より粒径3〜 $13 \mathrm{~mm}$ の礫を用いた粗粒材養浜が 開始された。明石海岸は長さ $1 \mathrm{~km}$ の海岸で, ほぼ全線に わたり消波堤が設置され, 前浜はほとんど存在しない. わずかにある砂浜は粒径約 $0.2 \mathrm{~mm}$ の細砂で構成されてい る. 粗粒材養浜の開始後明石海岸では前浜が次第に広が ったが，養浜後の定点写真観測によると，静穏波作用時 には養浜によって形成された礫浜の表面に細砂が堆積す る一方, 高波浪時には表面の細砂層が消失するとともに 養浜磁が岸側へと打込まれるという現象が確認された (古谷ら，2010）。静穏波条件での砂斜面への細砂の堆積 は, 礫床上では遡上波が急速に浸透するため, 戻り流れ のエネルギーが激減したためと考えられる，したがって 粗粒材養浜により形成された磁浜上での浸透による砂の 持つ平衡勾配の変化を考慮すれば碟層上への細砂の堆積 が予測可能と考えられる。一方高波浪時における碟浜表 面に堆積していた細砂の沖向き流出は, 高波浪による砂 の平衡勾配の減少により説明され, その上で礫の平衡勾 配は一定のまま波の遡上高が増大したと考えれば鿬の打 込みも予測可能と考えられる. 本研究では, 明石海岸で

\begin{tabular}{|c|c|c|}
\hline \multicolumn{2}{|c|}{1 学生会員 } & $\begin{array}{l}\text { 日本大学大学院理工学研究科海洋建築工 } \\
\text { 学専攻 }\end{array}$ \\
\hline 2 正会員 & 工博 & 日本大学教授 理工学部海洋建築工学科 \\
\hline 正会員 & 工博 & $\begin{array}{l}\text { (財)土木研究センター常務理事なぎさ } \\
\text { 総合研究室長兼日本大学客員教授理工学 } \\
\text { 部海洋建築工学科 }\end{array}$ \\
\hline & 博 (工) & ネット \\
\hline
\end{tabular}

観察された静穏波作用時における細砂の堆積助長機構 と, 荒天時の細砂の流出および礫の打込みについて, 等 深線変化モデルを用いて調べた.

\section{2. 観測方法}

明石海岸は，7号へッドランド（HL）を挟んで粗粒材 養浜の行われた神向寺海岸の北隣に位置する（図-1). 養 浜は7 号 HLの北側隣接部から開始され, その後海岸中央 部からも粗粒材の投入が行われた. 本研究の対象区域は 7 号 HL 隣接部での養浜である. 粗粒材養浜後の海浜変形 機構を調べるために，碟投入直後の 2009 年 1 月 28 日より HL と護岸上の定点（Q, P点）から写真撮影を行った. 養 浜に用いた粗粒材は黒いのに対し明石海岸に元々ある砂 は白いため, 粗粒材と海浜砂とは顕著な対比をなす。こ のため粗粒材の移動状況や粗粒材上への砂の堆積状況を 写真により判別可能であった（古谷ら，2010）.さらに 同じ粗粒材養浜が行われた神向寺海岸の 6 号 HL の北 $160 \mathrm{~m}$ に位置する測線No.32において縦断測量と堆積状況 調査を 2009 年 8 月 8 日に行った。 また観測期間中の波浪 条件については鹿島港の波浪観測が中断されておりデー 夕の取得ができないため, 明石海岸の北 $45 \mathrm{~km}$ に位置す る常陸那珂港のNOWPAHS データを参照した. 潮位条件 は銚子漁港における気象庁の予測值より調べた.

\section{3. 定点観測の結果}

定点写真観測の結果, 静穏時と荒天時の海浜状況に明 確な違いが見られた。図-2(a) は，2009年2月10日の海 岸状況である。既にこの時までに粗粒材養浜が行われ, 緩傾斜護岸ののり先と平行に設置されていた消波堤の半 ばを埋めて砂が堆積していた。消波堤の海側では白く見 えるように礫層の上に砂が堆積していた。 これに対して 


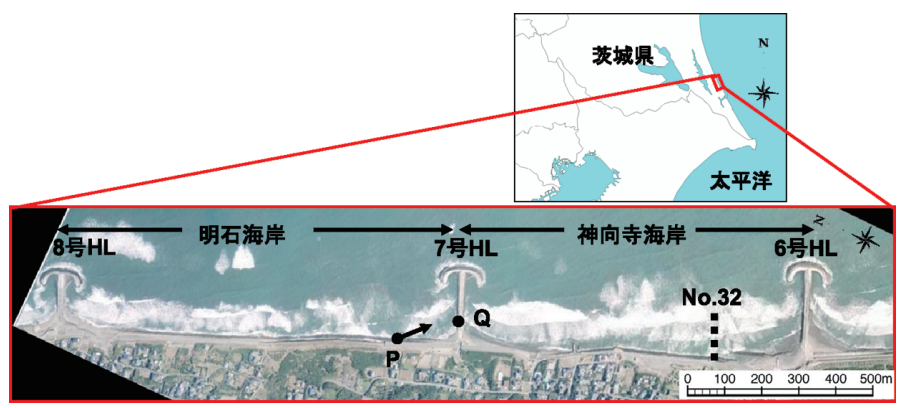

図-1 明石海岸と神向寺海岸の位置

(a) 2009 年 2 月 10 日 10 時 （潮位 T.P. $-0.2 \mathrm{~m}$ )

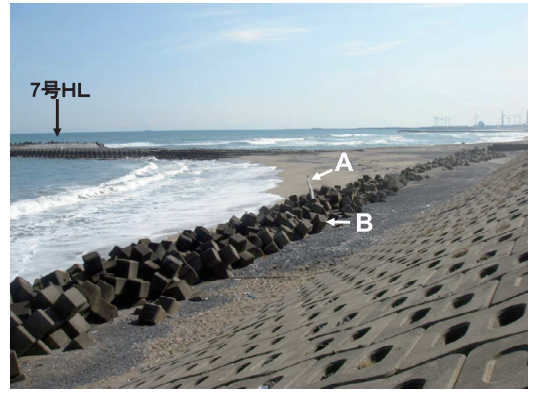

(b) 2009 年 3 月 26 日 10 時 (潮位 T.P. $-0.6 \mathrm{~m}$ )

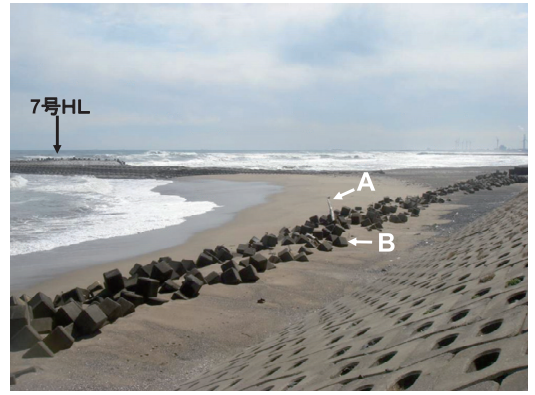

図-2 2009年2月10日と2009年3月26日の海岸状況の変化 (細砂堆積期)

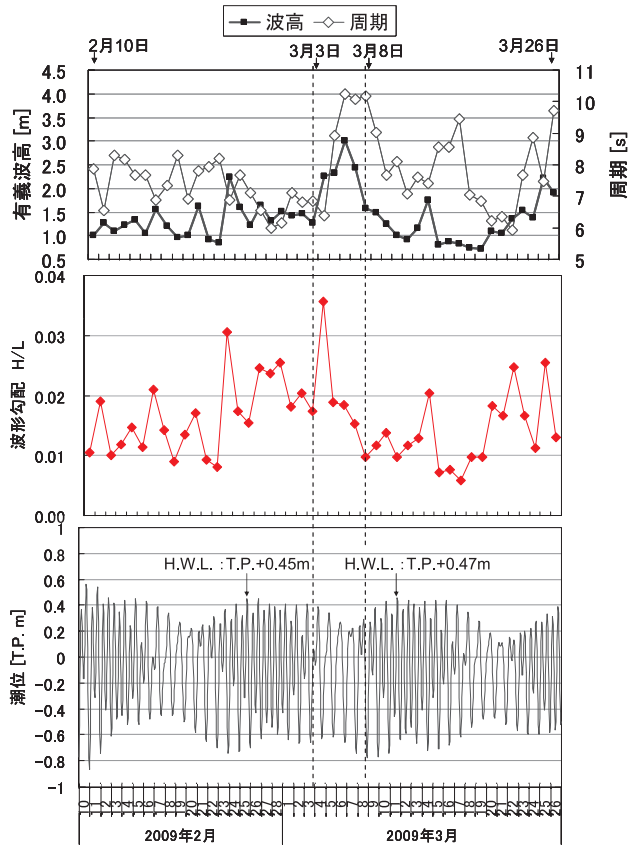

図-3 2009年2月 10 日から 2009年3月26日の波浪条件 (細砂堆積期)
消波堤より陸側はほとんどの区域が碟で覆われていた。 この状態から46日が経過した2009年3月26日の同じ場所 の状況を図-2(b) に示す。図-2(a)（b) において，消波堤 に突き刺さった流木を $\mathrm{A}$ ，その下部の異形ブロックを $\mathrm{B}$ として比較すると，2月10日にはBの頭が砂礫上に突き 出ていたが，3月26日には頭の部分を残してほぼ砂に埋 まっていることから，岸向きに運ばれた砂が砂碟上に堆 積し, 約 $0.4 \mathrm{~m}$ 海浜地盤高が上昇したことが分かった.

図-3はこの間の波浪・潮位条件の変化を示す。 $\mathrm{H}_{1 / 3}$ の 変化によれば，2月 10 日から 3 月 3 日までは平均波高 $1.31 \mathrm{~m}$ （平均波形勾配 0.016）の静穏な状態が続き，その 後3月 4 日から 3 月 7 日には低気圧の通過に伴い3月6日に は最大有義波高 $3.01 \mathrm{~m}$ （周期 $10.2 \mathrm{~s}$ ）の高波浪が来襲した。 しかし3月8日〜3月26日では再び静穏な状態となり，こ

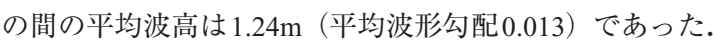

以上のように 2 月 10 日〜 3 月 3 日に静穏な状態が続いたこ とから前浜に砂が堆積したが，3月4日〜3月7日に高波 浪が来襲したため，前浜に堆積した砂は沖向きに運ばれ たと推定される。しかし，その後 3 月 25 日の $\mathrm{H}_{1 / 3}=2.21 \mathrm{~m}$ の波を除けば，3月26日まで相対的に静穏な波が作用し たため図-2のように異形ブロックがほぼ砂に埋まるまで 細砂の堆積が進んだと考えられる。

粗粒材養浜におけるもう一つの特徵は，高波浪の作用 時，遡上高の高まりに応じて礫が陸側に打込まれたこと である。図-4 (a) は2009年 8 月 8 日の海浜状況を示す. この時期は粗粒材の投入が行われていた時期であり，消 波堤の海側には碟が敷き並べつつあったが，消波堤と緩 傾斜護岸の間は砂磁が堆積し砂の色が白かった。しかし 2009年9月 1 日には図-4（b）のように消波堤より陸側に 粗粒材が打込まれ海浜全体が黒くなった。異形ブロック 
(a) 2009 年 8 月 8 日 12 時（潮位 T.P. $-0.6 \mathrm{~m}$ )
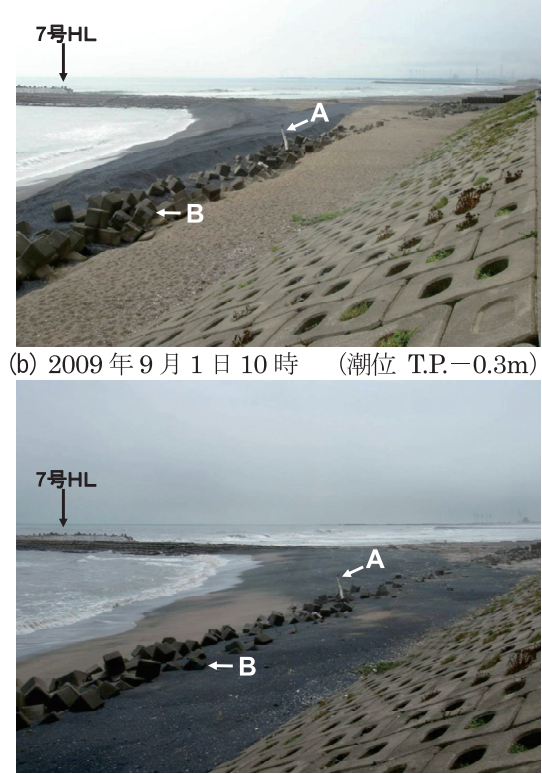

図-4

2009 年 8 月 8 日から 2009 年 9 月 1 日の海岸状況の変化 (礫堆積期)

$\mathrm{B}$ 付近での地盤高の上昇量は約 $0.7 \mathrm{~m}$ であった。この間の 波浪条件を図-5に示すが, 観測開始21日目の8月29日ま では平均有義波高 $0.97 \mathrm{~m}$ の静穏な状態が続いた。しかし 8 月 30 日には台風 11 号に伴う最大有義波高 $5.12 \mathrm{~m}$ （周期 8.6s）の波が作用した.8月29日までは静穏波が作用し粗 粒材の上に細砂が堆積したが, 高波浪の作用により粗粒 材が短時間のうちに岸向きに打ち上げられたと考えられ, 高波浪時粗粒材は岸向き移動が卓越することが分かった。

\section{4. 砂層厚調査の結果}

宇多ら（2007）によると粗粒材養浜で形成された礫浜 の勾配は約1/7である. 明石海岸に元々あった砂浜の構 成材料は粒径 $0.2 \mathrm{~mm}$ の細砂であるが, 神向寺海岸の縦断 形によれば, 細砂の平衡勾配は $1 / 50$ 程度と考えられるの で, これよりはるかに急な $1 / 7$ 勾配の礫浜に細砂の堆積 が可能になったのは, 砂浜の浸透効果によると考えられ る.そこで粗粒材養浜で形成された硶浜と, その上に細 砂が堆積してできた細砂層の勾配を神向寺海岸の測線 No.32で実測した結果を図-6に示す. 図中のム印は砂層 と礫層の境界面を示す。またメ印はその点より浅い部分 が砂層であることが確認された点である．鉛直方向に計 測した砂層厚は, バーム頂の $\mathrm{Z}=2.0 \mathrm{~m}$ 付近で約 $30 \mathrm{~cm}$, 層 厚を確認できた最も標高の低い $\mathrm{Z}=0.0 \mathrm{~m}$ で約 $80 \mathrm{~cm}$ であっ た. $\mathrm{X}=50 \mathrm{~m} \sim 60 \mathrm{~m}$ 付近（図-6, ×印）では，掘削中に地 下水位に達したため䃉層位置を測定できなかった。

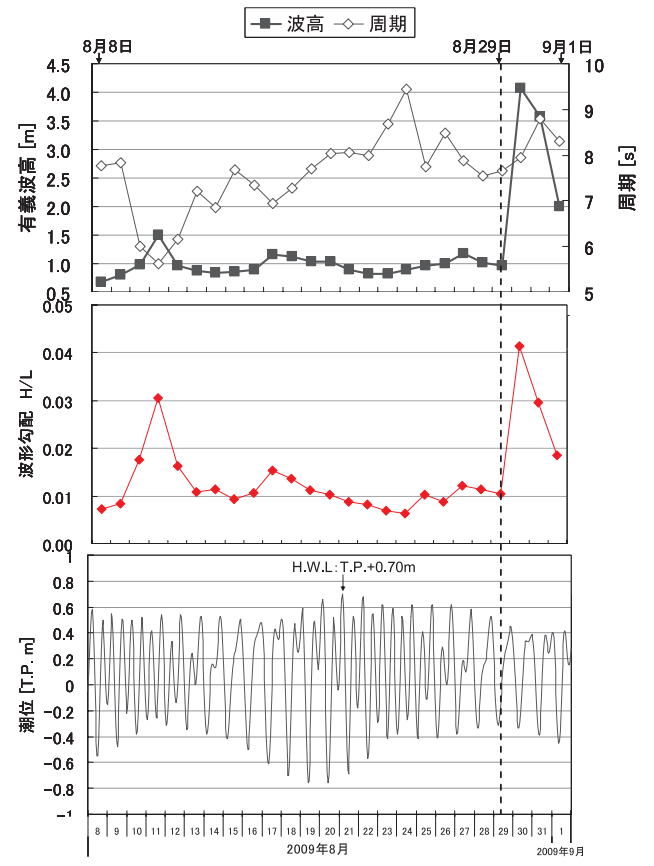

図-5 2009年8月 8 日から 2009年9月 1 日の波浪条件 (礫堆積期)

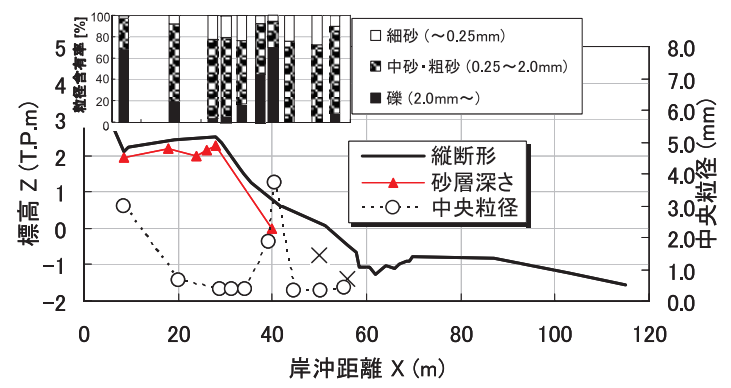

図-6 神向寺海岸の測線No.32における縦断形と砂層厚分布

$\mathrm{X}=30 \mathrm{~m} \sim 40 \mathrm{~m}$ （図-6，田印）の前浜では，地中の礫層勾 配が約 $1 / 5$ であるのに対し, 砂層の前浜勾配もほほ同じ 1/6であり, 汀線へ近づくと徐々に緩勾配となり砂層厚も 厚くなる.そして $\mathrm{Z}=-1.0 \mathrm{~m}$ 以下では $1 / 45$ 勾配となる. 図 には表層材料を採取・穊い分け分析により求めた中央粒 径の分布も示すが，前浜に打ち上げられた礫を採取した 2 点を除くと中央粒径は $0.35 \mathrm{~mm}$ であった.

\section{5. 予測モデル}

神向寺海岸の砂層厚調査の結果, 前浜勾配は砂の粒径 に応じた平衡勾配と比較して非常に大きな值を取ってお り, 鿬床の浸透効果が影響していることを伺わせる. 縦 断形変化を等深線モデルで再現するため, 調查で得られ た最も薄い砂層厚 $0.28 \mathrm{~m}$ を砂層厚の閾值とし, これを岸 沖距離に換算した砂層幅 $2 \mathrm{~m}$ を細砂堆積時の限界層厚と 
した。野志ら（2008）による粒度組成を考慮した等深線 変化モデルを適用した。野志らによる岸沖漂砂量式を以 下に示す.

$$
\begin{aligned}
& q_{z}^{(k)}=\mu^{(k)} \cdot \varepsilon_{z}(z) \cdot \gamma \cdot K_{1}^{(k)} \cdot\left(E C_{g}\right)_{b} \cos ^{2} \alpha_{b s} \sin \bar{\beta} . \\
& \left\{r \cdot\left(\cot \beta / \cot \overline{\beta_{c}}-1\right)+(1-r) \cdot\left(\cot \beta / \cot \beta_{c}^{(k)}-1\right)\right\} \\
& \text {; } k=1,2, \cdots, N, \quad 0 \leq r \leq 1 \quad \cdots(1) \\
& K_{1}^{(k)}=\frac{A}{\sqrt{d^{(k)}}} \\
& \varepsilon_{z}(z)=\left\{\begin{array}{rr}
\left(2 / h_{C}^{3}\right)\left(h_{C} / 2-z\right)\left(z+h_{C}\right)^{2},-h_{C} \leq z \leq h_{R} \\
0, \quad z \leq-h_{C}, \quad z \geq h_{R}
\end{array}\right.
\end{aligned}
$$

ここに $z$ はある等深線を表す高さ, $q_{z}^{(k)}, k=1,2, \cdots, N, 0 \leq r \leq 1$ は，標高 $z$ におけるある粒径 $k$ の岸沖漂砂量， $\mu^{(k)}$ は交換 層内の粒径ごとの含有率, $\varepsilon_{z}(z)$ は宇多・河野（1996）の 漂砂量の水深方向分布関数, $d^{(k)}$ は底質粒径を示し, 単位 は $\mathrm{mm}$ とする. A は係数で, 対象海岸の変形過程に応じ て設定する。すなわち $A$ は次元を持った係数であり，経 験的に $0.3 \sim 0.5 \mathrm{~mm}^{-2}$ の範囲の值を使用する. $\gamma$ は岸沖 · 沿岸方向の漂砂量係数の比率であり, 沿岸漂砂に対する 岸沖漂砂の動き易さを表す. $\left(E C_{g}\right)_{b}$ は砕波点のエネルギ ーフラックス， $\alpha_{b s}$ は砕波点において波峰線が等深線とな す角, $\beta$ は縦断傾斜角, $\bar{\beta}$ は初期傾斜角である. $h_{R}$ はバー 厶高, $h_{C}$ は波による地形変化の限界水深である。野志ら の式では， $\bar{\beta}_{C}$ を複数の粒度組成に応じた平衡勾配， $\beta_{C}{ }^{(k)}$ をある粒径 $k$ の平衡勾配とし，第1項は粒度組成に応じた 平衡勾配に，第2 項は粒径それぞれが単体として持つ平 衡勾配に近づこうとする岸沖漂砂を表している. 全岸沖 漂砂量は, これら2つの特性を有する岸沖漂砂量の加重 平均で表す。なお, 重み $r$ は対象海岸の海浜変形特性に 応じて設定するものとし，粒径の岸沖分級作用が強く働 く海岸においては $r$ を 0 に近づける．逆に岸沖分級作用が あまりない海浜においては $r$ を 1 に近づける。本研究では 重み $r$ は両者の作用がほぼ等しい条件として 0.5 とした。

\section{6. 計算の基本的考え方と計算条件}

まず静穏波が作用し，岸向き漂砂が卓越する状態を考 える.この条件のもとで䃇床上での細砂の堆積が浸透効 果に起因するならば，細砂の堆積が始まった直後に碟床 の浸透効果が最も発揮されるはずである。この効果によ り細砂が本来有する平衡勾配よりも急な斜面上に細砂が 堆積すると考えられる。しかしある程度砂層が発達する と, 砂層厚の増加に伴い礫床への海水の浸透能が弱まり, 砂層の勾配は細砂本来の平衡勾配に近づくと考えられ る．再現計算ではこの考えをもとに，砂層厚に応じて䃇 床上に堆積する細砂の平衡勾配を変化させることで現地 で見られた現象の再現を試みた。

宇多ら（2007）によれば，粗粒材養浜によって形成さ
れた礫浜の勾配は約 $1 / 7$ であり，また明石・神向寺海岸 のT.P.-2.0m 以深はほぼ1/100の緩勾配である.よって再 現計算に用いる初期地形条件としては，図-7に示すよう に $\mathrm{Z}=-1.0 \mathrm{~m}$ で $1 / 7$ 勾配から $1 / 100$ 勾配に折れた複断面を初 期縦断形とした。その場合の初期粒径含有率は, 宇多ら （2007）による神向寺海岸における碟養浜の追跡調査結 果を参考とし, 試験施工前に行われた沖浜底質の砂の含 有率（細砂：中砂 $=7 ： 3 ）$ を設定した。礫表面への砂の 堆積は，3.で述べたように2009年3月 8 日〜3月 26 日の静 穏条件（平均波高 $1.24 \mathrm{~m}$ ) で起きたので，このような静 穏条件で上記現象が起こると考えた。その場合の砂層形 成は，バーム頂の $\mathrm{Z}=2 \mathrm{~m}$ までとした，前浜斜面上では礫 浜の浸透効果により磁斜面と同じ $1 / 7$ 勾配で細砂が堆積 するものとし，1/7勾配砂層幅の水平方向の増分 $2 \mathrm{~m}$ に見 合う分細砂が，岸向きに運ばれ堆積すると考える。しか し砂層幅が闇值の $2 \mathrm{~m}$ を超え, 礫床の浸透効果が弱まる 場所では，それ以上の堆積はなくなると考えた.

一方，8月30日には台風 11 号に伴う最大有義波高 $5.12 \mathrm{~m}$ (周期 8.6s) の波が作用し，8月 29 日までに粗粒材 上に堆積していた細砂は短時間で流出し, 礫は岸向きに 打ち上げられた。このような高波浪作用時には，砂以外 の土砂の平衡勾配を沖浜勾配と同一の $1 / 100$ と緩くし (福濱ら，2008），かつバーム高を $2.0 \mathrm{~m}$ から $3.0 \mathrm{~m}$ に上昇 させれば計算が可能である。表-1には計算条件をまとめ て示す.なお投入礫の径は $3 \sim 13 \mathrm{~mm}$ であるが，計算で

\begin{tabular}{|c|c|c|c|c|}
\hline \multirow{2}{*}{\multicolumn{3}{|c|}{ 計算ケース }} & 1 & 2 \\
\hline & & & 静穏時 & 荒天時 \\
\hline \multirow{5}{*}{$\begin{array}{c}\text { 初期粒径と } \\
\text { 含有率 }\end{array}$} & $Z=5.0 \sim 0.0(\mathrm{~m})$ & 磞, $7.5 \mathrm{~mm}$ & $100 \%$ & \\
\hline & \multirow{4}{*}{$Z=-1.0 \sim-10.0(\mathrm{~m})$} & 細砂, $0.106 \mathrm{~mm}$ (被浸透効果) & $5 \%$ & \\
\hline & & 中砂, $0.425 \mathrm{~mm}$ (被浸透効果) & $10 \%$ & \\
\hline & & 中砂, $0.425 \mathrm{~mm}$ & $20 \%$ & \\
\hline & & 細砂, $0.106 \mathrm{~mm}$ & $65 \%$ & \\
\hline \multirow{5}{*}{\multicolumn{2}{|c|}{ 平衡勾配 }} & 磂, $7.5 \mathrm{~mm}$ & $1 / 7$ & $1 / 7$ \\
\hline & & 細砂, $0.106 \mathrm{~mm}$ (被浸透効果) & $1 / 7$ & $1 / 100$ \\
\hline & & 中砂, $0.425 \mathrm{~mm}$ (被浸透効果) & $1 / 7$ & $1 / 100$ \\
\hline & & 中砂, $0.425 \mathrm{~mm}$ & $1 / 45$ & $1 / 100$ \\
\hline & & 細砂, $0.106 \mathrm{~mm}$ & $1 / 100$ & $1 / 100$ \\
\hline \multicolumn{3}{|c|}{ 交換層幅B (m) } & 1.35 & 1.35 \\
\hline \multirow{3}{*}{ 入射波条件 } & \multicolumn{2}{|c|}{ 砕波波高 $H_{b}(\mathrm{~m})$} & 1.2 & 3.0 \\
\hline & \multicolumn{2}{|c|}{ 砕波波向 $\alpha_{b s}$ (deg.) } & 0.0 & 0.0 \\
\hline & \multicolumn{2}{|c|}{ 潮位条件M.S.L. (m) } & 0.0 & 0.0 \\
\hline \multirow{2}{*}{$\begin{array}{c}\text { 地形変化の } \\
\text { 水深範囲 }\end{array}$} & \multicolumn{2}{|c|}{ 地形変化の限界水深 $h_{C}(\mathrm{~m})$} & 6.0 & 8.0 \\
\hline & \multicolumn{2}{|c|}{ バーム高 $h_{R}(\mathrm{~m})$} & 2.0 & 3.0 \\
\hline 漂砂量係数 & \multicolumn{2}{|c|}{ 漂砂量係数 $A$} & 0.3 & 0.3 \\
\hline \multirow{2}{*}{$\begin{array}{c}\text { 土砂落ち込み } \\
\text { の限界勾配 }\end{array}$} & \multicolumn{2}{|c|}{ 陸域 } & $1 / 2$ & $1 / 2$ \\
\hline & \multicolumn{2}{|c|}{ 海域 } & $1 / 3$ & $1 / 3$ \\
\hline 計算範囲 & \multicolumn{2}{|c|}{ 鉛直方向 $Z(\mathrm{~m})$} & $-10 \sim 5$ & $-10 \sim 5$ \\
\hline 計算メッシュ & \multicolumn{2}{|c|}{$\Delta Z(\mathrm{~m})$} & 1.0 & 1.0 \\
\hline \multicolumn{3}{|c|}{ 計算時間間隔 $\Delta t(\mathrm{hr})$} & 0.05 & 0.0005 \\
\hline \multicolumn{3}{|c|}{ 計算ステップ数 } & 1,000 & 5,000 \\
\hline
\end{tabular}
は投入礫の $d_{50}$ の值を用いた.

\section{7. 予測結果}

図-7 は静穏波作用下での礫層上への細砂の堆積状況を

表-1 計算条件 


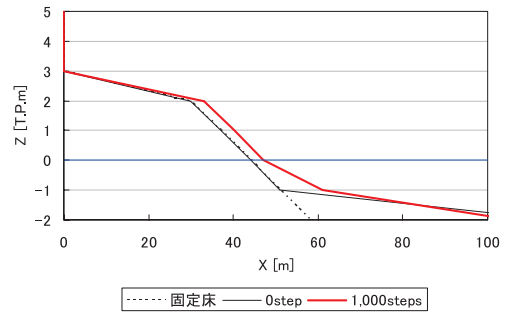

図-7＼cjkstart静穏波条件での䃋層上への砂の堆積状況

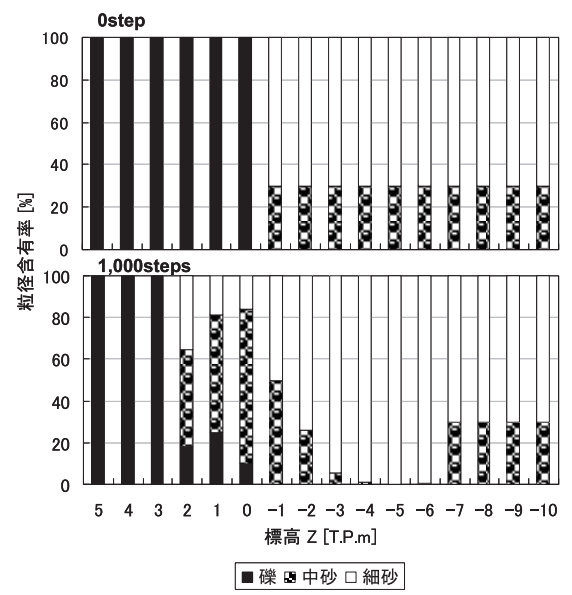

図-8 初期状態と 1,000 ステップ後の粒径含有率の水深方向分布

示す．また図-8には初期状態と 1,000 ステップ後の粒径含 有率の水深方向分布を示す. 砂浜の浸透効果が発揮され, 1/7勾配の磼浜に中砂細砂が覆いかぶさるように堆積する が，水面下では礫の浸透効果がなくなり，そこでは中砂 が集中的に堆積するため汀線近傍では中砂の平衡勾配 $1 / 45$ に近い勾配となる。本計算では $h_{c}=6 \mathrm{~m}, h_{R}=2 \mathrm{~m}$ とし ているので波の作用のない場所では当初の粒度組成が保 たれる。このようにして砂浜上に細砂が堆積した後高波 浪が作用し, 中砂細砂の持つ平衡勾配が一時的に小さく なったと仮定すると, 堆積した中砂細砂が再び沖向きに 移動する過程が予測できる。 さらに荒天時には磉の打込 みが起こる. 図-9は堆積砂層の消失と礫の打込久に伴う 縦断形変化を示す。また図-10には初期状態と 5,000 ステ ップ後の粒径含有率の水深方向分布を示す。高波浪時に は中砂細砂の平衡勾配がともに $1 / 100$ と小さくなるため 沖向き漂砂が活発化し，汀線付近が大きく掘られる。 ま たバーム高が高まるため砂は岸向きに移動し，砂層の上 に載っていた細砂は沖へと流出する.

\section{8. まとめ}

明石海岸では2008年 11月 11 日より粒径3〜13mm の礫 を用いた粗粒材養浜が開始されたが, 養浜後の定点写真 観測によると，静穏波作用時には養浜によって形成され

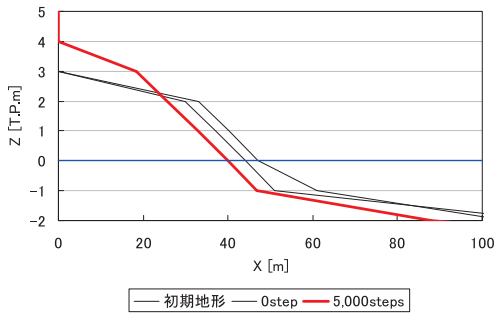

図-9＼cjkstart高波浪時の礫の打ち上げ

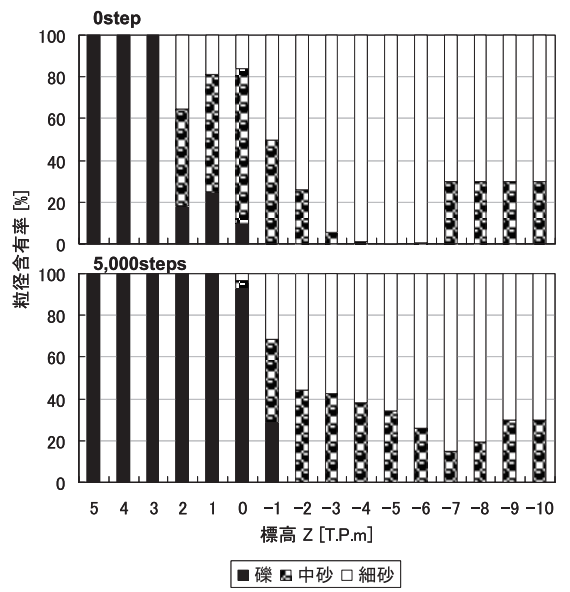

図-10 初期状態と 5,000 ステップ後の粒径含有率の水深方向分布

た礫浜の表面に細砂が堆積する一方，高波浪時には表面 の細砂層は消失するとともに養浜啋が岸側へと打込まれ る現象が確認された。本研究ではこれらの観察結果のう ち, 磁浜における静穏波作用時に打ける細砂の堆積助長 機構について砂の平衡勾配の変化を考慮した等深線変化 モデルにより説明可能とした。また荒天時の磁の打込み についても等深線変化モデルにより説明が可能になった.

\section{参 考 文 献}

宇多高明 - 石井秀雄 - 阿部 良 - 長山英樹 - 大木康弘 (2007)：神向寺海岸における礫養浜の追跡調查, 海洋開 発論文集，第23卷，pp. 1093-1098.

宇多高明・河野茂樹（1996）：海浜変形予測のための等深線変 化モデルの開発，土木学会論文集，No.539/II-35, pp. 121139 .

古谷真広・小林昭男 - 宇多高明 - 野志保仁 (2010)：明石海岸 における磉養浜後の海浜状況変化，海洋開発論文集，第 26卷, pp. 1053-1057.

野志保仁 - 小林昭男 - 宇多高明 - 熊田貴之 · 芹沢真澄 （2008）：粒度組成と個々の粒径に対応した複合平衡勾配 を考虑した海浜地形・粒径変化予測モデル，地形， Vol.29, pp. 399-419.

福濱方哉・宇多高明 - 山田浩次 - 芹沢真澄 - 石川仁憲 (2008)：前浜勾配と汀線の短期変動の予測モデル，海洋 開発論文集，第24卷，pp. 1237-1242.

松浦健郎 - 宇多高明 - 諏訪義雄 - 山田浩次 - 福本崇嗣 （2009）：砂浜の海岸保全施設指定に向けた粗粒材養浜の 有効性の検討, 海洋開発論文集, 第25巻, pp. 1119-1124. 